\title{
Salmonella O48 Serum Resistance is Connected with the Elongation of the Lipopolysaccharide O-Antigen Containing Sialic Acid
}

\author{
Aleksandra Pawlak ${ }^{1, *}$, Jacek Rybka ${ }^{2}$, Bartłomiej Dudek ${ }^{1}$, Eva Krzyżewska ${ }^{2}$, Wojciech Rybka ${ }^{2}$, \\ Anna Kędziora ${ }^{1}$, Elżbieta Klausa ${ }^{3}$ and Gabriela Bugla-Płoskońska ${ }^{1, *}$ \\ 1 Department of Microbiology, Institute of Genetics and Microbiology, University of Wrocław, \\ 51-148 Wrocław, Poland; bartlomiej.dudek@uwr.edu.pl (B.D.); anna.kedziora@uwr.edu.pl (A.K.) \\ 2 Department of Immunology of Infectious Diseases, Hirszfeld Institute of Immunology and Experimental \\ Therapy, Polish Academy of Sciences, 53-114 Wrocław, Poland; rybka@iitd.pan.wroc.pl (J.R.); \\ eva.krzyzewska@iitd.pan.wroc.pl (E.K.); wrybka@iitd.pan.wroc.pl (W.R.) \\ 3 Regional Centre of Transfusion Medicine and Blood Bank, 50-345 Wrocław, Poland; \\ e.klausa@rckik.wroclaw.pl \\ * Correspondence: aleksandra.pawlak@uwr.edu.pl (A.P.); gabriela.bugla-ploskonska@uwr.edu.pl (G.B.-P.); \\ Tel.: +48-71-375-62-28 (A.P.); +48-71-375-63-23 (G.B.-P.)
}

Received: 7 August 2017; Accepted: 12 September 2017; Published: 21 September 2017

\begin{abstract}
Complement is one of the most important parts of the innate immune system. Some bacteria can gain resistance against the bactericidal action of complement by decorating their outer cell surface with lipopolysaccharides (LPSs) containing a very long O-antigen or with specific outer membrane proteins. Additionally, the presence of sialic acid in the LPS molecules can provide a level of protection for bacteria, likening them to human cells, a phenomenon known as molecular mimicry. Salmonella $\mathrm{O} 48$, which contains sialic acid in the O-antigen, is the major cause of reptile-associated salmonellosis, a worldwide public health problem. In this study, we tested the effect of prolonged exposure to human serum on strains from Salmonella serogroup O48, specifically on the O-antigen length. After multiple passages in serum, three out of four tested strains became resistant to serum action. The gas-liquid chromatography/tandem mass spectrometry analysis showed that, for most of the strains, the average length of the LPS O-antigen increased. Thus, we have discovered a link between the resistance of bacterial cells to serum and the elongation of the LPS O-antigen.
\end{abstract}

Keywords: serum resistance; complement; Salmonella; lipopolysaccharide; sialic acid; reptile-associated salmonellosis

\section{Introduction}

Complement, a component of blood serum of vertebrates, is one of the most important parts of the immune system, playing a decisive role in the defense of the host against infections. Its activation during infections can lead to sepsis [1,2]. Complement can be activated via the classical, alternative, or lectin pathways. Because of the presence of complement and other parts of the immune system, e.g., lysozymes, human serum is an extremely unfavorable environment for bacterial survival and growth. However, several bacteria have established a number of strategies protecting them from these conditions, one being the molecular mimicry phenomenon [3-5]. For instance, the LPSs of some bacteria contain sialic acid ( $N$-acetylneuraminic acid, NeuAc), which enables them to mimic human cells and avoid the bactericidal action of serum [3-5]. Non-typhoidal Salmonella (NTS) organisms pose a significant epidemiological problem all over the world [6-12]. Each year Salmonella rods are the causative agents of 93.8 million cases of gastroenteritis worldwide, of which 155,000 are fatal [6]. According to the CDC (Center for Disease Control and Prevention) only 1-5\% of Salmonella infections 
are laboratory confirmed and reported, so the real number of salmonellosis cases is much higher [13]. Salmonellosis is the most common illness among food-borne diseases, in some instances leading to hospitalization and death $[9-11,13,14]$. NTS infections usually cause diarrhea, although they can also lead to extra-intestinal infections, including bacteremia, sepsis, and in rare cases miscarriage [15-18]. Salmonellosis is a zoonotic infection; the animal sources of Salmonella rods are inter alia: birds, cattle, pigs, horses, rodents, dogs, cats, reptiles, or amphibians [13,16,19], with reptiles being reported as the most common source of Salmonella causing RAS (reptile-associated salmonellosis). Most reptiles are asymptomatic carriers of Salmonella [17,20-22]. However, transmission of these bacteria from reptiles to humans occurs frequently, sometimes leading to sepsis, affecting mainly children under 5 years of age, immunocompromised patients, and AIDS (acquired immune deficiency syndrome) patients $[13,16,17,20-22]$. Recently, the term REPAS (reptile exotic pet-associated salmonellosis) was proposed for these infections in the literature [20], to point out that the main source of salmonellosis in humans are non-native reptiles, as the data show that the main carriers of Salmonella are reptiles kept in captivity as pets, not wild ones [20,22]. RAS/REPAS cases lead more frequently to hospitalizations than salmonellosis not connected to reptiles. There is an increasing trend in RAS/REPAS incidence, especially among children under 3 years of age [20], which is probably connected with the current trend for breeding reptiles in households [23-25]. A common causative agent of RAS/REPAS is Salmonella from the O48 serogroup, containing sialic acid in the structure of lipopolysaccharides (LPSs) [26-28]. As mentioned before, the presence of NeuAc, a common constituent in outer structures of both higher organisms and bacteria, can represent the molecular mimicry phenomenon, as it can protect bacterial cells from the complement lytic action [3-5]. Sialic acid can also bind the complement factor $\mathrm{H}$, resulting in the inhibition of the alternative pathway activation [29]. LPS is a component of the outer cell membrane, characteristic of most Gram-negative bacteria. LPS is built up of three main parts: lipid A, the inner and outer core, and the O-specific polysaccharide chain. Lipid A, anchoring the structure in the hydrophobic membrane, is linked to the non-repeating oligosaccharide core, while the O-specific chain linked to the core oligosaccharide can contain up to 70-100 repeating oligosaccharide units among different Salmonella strains. Each repeating unit is built up of two to eight monosaccharide residues, e.g., mannose, rhamnose, galactose, or sialic acid $[19,28,30]$. The presence of terminal NeuAc in the O-antigen units $[28,31]$ renders the LPS structure similar to human glycosphingolipids and enables it to take part in the molecular mimicry phenomenon. Due to its high structural variability, the O-polysaccharide chain is used in serological classification as an O-antigenic determinant. The basic function of the O-chain is the protection of bacteria from host immune response (especially the alternative complement cascade and phagocytosis) [30,32]. A shortened O-specific chain of LPS is a possible reason for its bacterial sensitivity to human serum [33-35]. In our previous study [19], we demonstrated that various serovars of Salmonella $\mathrm{O} 48$ with the same structure of the O-specific antigen differed in the number of repeating units (measured as the NeuAc/Kdo ratio). However, the average length of the O-antigen did not correlate with bacterial cells' susceptibility to human blood serum action. In the present study, we concentrated on the role of sialic acid in bacterial resistance to serum. Serum, as a challenging environment for bacterial growth, can enforce various modifications in bacterial outer structures, which can build up the protection against complement activity. In this study, we investigated whether prolonged contact of Salmonella O48 cells with human serum (multiple passages) can lead to any changes in the average length of the LPS O-specific antigen, measured as the NeuAc/Kdo ratio, and changes in bacteria susceptibility to human blood serum.

\section{Results}

\subsection{The C3 Concentration in Serum}

The level of C3 in the human serum used in this study was $1240 \mathrm{mg} / \mathrm{L}$. This result is within the normal range for males (970-1576 mg/L) and females (1032-1495 mg/L) (Human Complement C3 \& C4: "Nl" BindaridTM Radial Immunodiffusion Kit; The Binding site Group Ltd., Birmingham, UK). 


\subsection{Passages of Bacteria in NHS (Normal Human Serum)}

The strains used in the following experiments were previously tested for their initial length of the LPS O-specific antigen [19]. All chosen strains were initially sensitive to $50 \%$ human serum action (which was confirmed three times) and differed substantially in the O-antigen average length: $S$. Hammonia with the highest NeuAc/Kdo ratio of $256 \%$, S. Erlangen and S. Bongori with an intermediate ratio $(87 \%$ and $41 \%$, respectively), and S. Isaszeg with the lowest NeuAc/Kdo ratio (at the detection limit). These results were precisely described in our previous study [19]. Here, we found that the susceptibility of the tested strains (S. Erlangen, S. Isaszeg, S. Hammonia, and S. Bongori) to normal human serum (NHS) action changed during the passages in NHS (Figure 1, Table 1). At the start of the experiments, all tested strains were sensitive to bactericidal action of $50 \%$ NHS. The survival after $3 \mathrm{~h}$ (T3) of incubation in serum was $0.001 \%$ for $S$. Erlangen, $0.04 \%$ for $S$. Isaszeg, $\leq 0.00009 \%$ for $S$. Bongori, and $0.06 \%$ for $S$. Hammonia. During the passages, three tested strains (S. Erlangen, $S$. Isaszeg, and $S$. Hammonia) showed a tendency to a biphasic process, shown in Figure 1 . They significantly increased the survival percentage, twice during nine passages. After prolonged contact of bacterial cells with serum (nine passages in serum), three out of four tested strains (S. Erlangen, $S$. Isaszeg, $S$. Hammonia) became resistant to serum. After nine passages in serum, the percentage survival of S. Erlangen, S. Isaszeg, and S. Hammonia cells was $200 \%, 183.78 \%$, and $491.80 \%$, respectively. $S$. Bongori was still not considered as resistant to serum after nine passages, although its survival after prolonged contact with NHS increased substantially up to 20,000 times (from $\leq 0.00009$ in the first passage to $1.80 \%$ in the ninth passage). All tested strains incubated for $3 \mathrm{~h}$ in NHS or heated at $56{ }^{\circ} \mathrm{C}$ for $30 \mathrm{~min}$ (control) proliferated very intensively (Table 2), as the heating removed the bactericidal activity of the serum. Bacterial cells of all tested strains obtained after the ninth passage in NHS were transferred into fresh LB (lysogeny broth) medium with glycerol and frozen in $-70^{\circ} \mathrm{C}$. After three months, all frozen strains were re-examined and their susceptibility to bactericidal activity of $50 \%$ NHS (survival percent) was compared to results obtained after passage 9 . The results indicated that all tested strains (S. Erlangen, $S$. Isaszeg, $S$. Hammonia, and $S$. Bongori) generally maintained the resistance achieved by prolonged contact with serum. The survival of bacterial cells after $3 \mathrm{~h}$ of incubation with serum was higher than $100 \%$ for S. Erlangen $(643.68 \%)$, for S. Isaszeg $(112.77 \%)$, and S. Hammonia $(733.33 \%)$, while for $S$. Bongori the resistance remained weak $(0.05 \%)$. Serum heated at $56^{\circ} \mathrm{C}$ for $30 \mathrm{~min}$ was used as a control. In these conditions, all tested strains proliferated intensively (Table 2). 


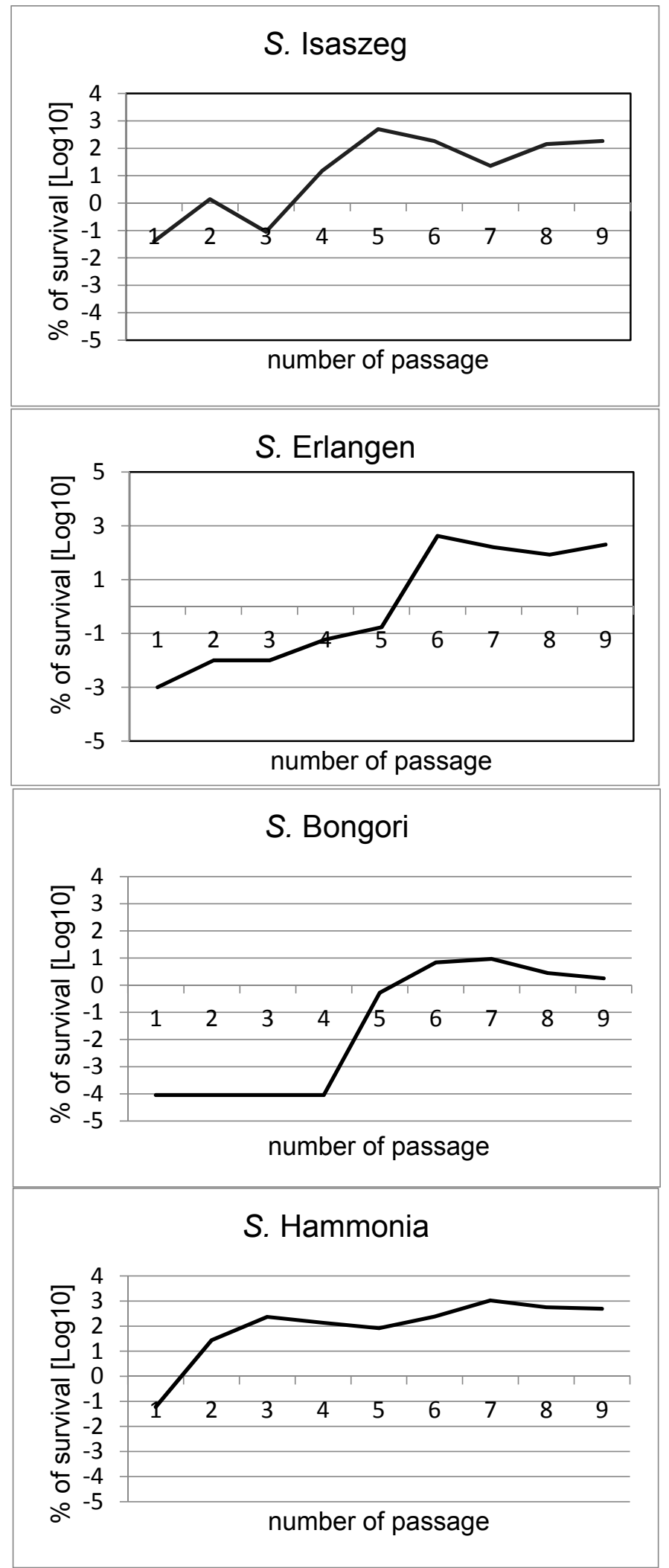

Figure 1. Survival percent of Salmonella O48 strains during nine passages in $50 \%$ NHS (normal human serum). 
Table 1. Bactericidal activity against Salmonella O48 strains during passages in 50\% NHS.

\begin{tabular}{|c|c|c|c|c|c|c|c|c|c|c|c|c|}
\hline \multirow{3}{*}{$\begin{array}{l}\text { Number of } \\
\text { Passages }\end{array}$} & \multicolumn{3}{|c|}{ S. Hammonia } & \multicolumn{3}{|c|}{ S. Isaszeg } & \multicolumn{3}{|c|}{ S. Bongori } & \multicolumn{3}{|c|}{$S$. Erlangen } \\
\hline & \multicolumn{2}{|c|}{$\mathrm{CFU} / \mathrm{mL}^{*}$} & \multirow{2}{*}{$\begin{array}{c}\text { Survival of } \\
\text { Cells at T3 (\%) }\end{array}$} & \multicolumn{2}{|c|}{$\mathrm{CFU} / \mathrm{mL}$} & \multirow{2}{*}{$\begin{array}{c}\text { Survival of } \\
\text { Cells at T3 (\%) }\end{array}$} & \multicolumn{2}{|c|}{$\mathrm{CFU} / \mathrm{mL}$} & \multirow{2}{*}{$\begin{array}{c}\text { Survival of } \\
\text { Cells at T3 (\%) }\end{array}$} & \multicolumn{2}{|c|}{$\mathrm{CFU} / \mathrm{mL}$} & \multirow{2}{*}{$\begin{array}{r}\text { Survival of } \\
\text { Cells at T3 }(\%\end{array}$} \\
\hline & T0 & T3 & & T0 & T3 & & T0 & T3 & & T0 & T3 & \\
\hline 1 & $1.7 \times 10^{6}$ & $9.6 \times 10^{2}$ & 0.06 & $5.7 \times 10^{6}$ & $2.0 \times 10^{3}$ & 0.04 & $6.9 \times 10^{6}$ & $\leq 10^{0}$ & $\leq 0.00009$ & $5.1 \times 10^{6}$ & $5.5 \times 10^{1}$ & 0.001 \\
\hline 2 & $1.0 \times 10^{6}$ & $2.7 \times 10^{5}$ & 27.00 & $6.5 \times 10^{6}$ & $9.0 \times 10^{4}$ & 1.38 & $3.5 \times 10^{6}$ & $\leq 10^{0}$ & $\leq 0.00009$ & $7.1 \times 10^{6}$ & $7.1 \times 10^{2}$ & 0.01 \\
\hline 3 & $2.3 \times 10^{6}$ & $5.4 \times 10^{6}$ & 234.78 & $5.4 \times 10^{6}$ & $5.1 \times 10^{3}$ & 0.09 & $3.4 \times 10^{6}$ & $\leq 10^{0}$ & $\leq 0.00009$ & $8.4 \times 10^{6}$ & $9.2 \times 10^{2}$ & 0.01 \\
\hline 4 & $4.7 \times 10^{6}$ & $6.4 \times 10^{5}$ & 136.17 & $4.8 \times 10^{6}$ & $7.2 \times 10^{5}$ & 15.00 & $2.8 \times 10^{6}$ & $\leq 10^{0}$ & $\leq 0.00009$ & $4.2 \times 10^{6}$ & $2.6 \times 10^{3}$ & 0.06 \\
\hline 5 & $1.7 \times 10^{6}$ & $1.4 \times 10^{6}$ & 82.35 & $3.2 \times 10^{6}$ & $1.6 \times 10^{7}$ & 500.00 & $1.5 \times 10^{6}$ & $8.0 \times 10^{3}$ & 0.53 & $5.0 \times 10^{6}$ & $8.6 \times 10^{3}$ & 0.17 \\
\hline 6 & $1.0 \times 10^{6}$ & $2.4 \times 10^{6}$ & 240.00 & $3.7 \times 10^{6}$ & $6.8 \times 10^{6}$ & 183.78 & $3.2 \times 10^{6}$ & $2.2 \times 10^{5}$ & 6.88 & $2.0 \times 10^{6}$ & $8.5 \times 10^{6}$ & 425.00 \\
\hline 7 & $1.7 \times 10^{6}$ & $1.8 \times 10^{7}$ & 1058.82 & $3.4 \times 10^{6}$ & $7.8 \times 10^{5}$ & 22.94 & $4.5 \times 10^{6}$ & $4.2 \times 10^{5}$ & 9.33 & $3.2 \times 10^{6}$ & $5.1 \times 10^{6}$ & 159.38 \\
\hline 8 & $1.3 \times 10^{6}$ & $7.3 \times 10^{6}$ & 561.64 & $4.1 \times 10^{6}$ & $5.8 \times 10^{6}$ & 141.46 & $5.0 \times 10^{5}$ & $1.4 \times 10^{4}$ & 2.80 & $4.5 \times 10^{6}$ & $3.8 \times 10^{6}$ & 84.44 \\
\hline 9 & $6.1 \times 10^{6}$ & $3.0 \times 10^{7}$ & 491.80 & $3.7 \times 10^{6}$ & $6.8 \times 10^{6}$ & 183.78 & $5.0 \times 10^{6}$ & $8.1 \times 10^{4}$ & 1.80 & $3.0 \times 10^{6}$ & $6.0 \times 10^{6}$ & 200.00 \\
\hline
\end{tabular}

${ }^{*} \mathrm{CFU} / \mathrm{mL}-$ colony-forming units in milliliter; NHS: normal human serum.

Table 2. Bactericidal activity of $50 \%$ NHS decomplemented by heating at $56{ }^{\circ} \mathrm{C}$ for 30 min against Salmonella $\mathrm{O} 48$ strains.

\begin{tabular}{|c|c|c|c|c|c|c|c|c|c|c|c|}
\hline \multicolumn{3}{|c|}{ S. Hammonia } & \multicolumn{3}{|c|}{ S. Isaszeg } & \multicolumn{3}{|c|}{ S. Bongori } & \multicolumn{3}{|c|}{$S$. Erlangen } \\
\hline \multicolumn{2}{|c|}{$\mathrm{CFU} / \mathrm{mL}^{*}$} & \multirow{2}{*}{$\begin{array}{c}\text { Survival of } \\
\text { Cells at T3 (\%) }\end{array}$} & \multicolumn{2}{|c|}{$\mathrm{CFU} / \mathrm{mL}$} & \multirow{2}{*}{$\begin{array}{c}\text { Survival of } \\
\text { Cells at T3 (\%) }\end{array}$} & \multicolumn{2}{|c|}{$\mathrm{CFU} / \mathrm{mL}$} & \multirow{2}{*}{$\begin{array}{l}\text { Survival of } \\
\text { Cells at T3 (\%) }\end{array}$} & \multicolumn{2}{|c|}{$\mathrm{CFU} / \mathrm{mL}$} & \multirow{2}{*}{$\begin{array}{l}\text { Survival of } \\
\text { Cells at T3 (\%) }\end{array}$} \\
\hline T0 & T3 & & T0 & T3 & & T0 & T3 & & T0 & T3 & \\
\hline $4.6 \times 10^{6}$ & $5.1 \times 10^{7}$ & 1108.69 & $3.7 \times 10^{6}$ & $2.7 \times 10^{7}$ & 729.73 & $4.2 \times 10^{6}$ & $3.6 \times 10^{7}$ & 857.15 & $3.6 \times 10^{6}$ & $3.1 \times 10^{7}$ & 861.11 \\
\hline
\end{tabular}

${ }^{*} \mathrm{CFU} / \mathrm{mL}-$ colony-forming units in milliliter. 


\subsection{SDS-PAGE (SDS-Polyacrylamide Gel Electrophoresis) of LPS}

As the next step, the SDS-PAGE analysis of LPS isolated from bacterial cells before the passages and after ninth passage in 50\% NHS (normal human serum) was performed. The results showed that LPS isolated from all tested strains produced very long O-antigen (VL-OAg: more than $100 \mathrm{O}$-specific units in the O-chain; Figure 2). Such behavior is described in the literature as a factor influencing bacterial resistance to human serum [35,36]. Moreover, the comparison of the LPS profile of Salmonella O48 before passages in 50\% NHS (BP) and after the ninth passage (AP) shows distinct differences in the quantitative proportions between the short and long $\mathrm{O}$-antigen regions. In the case of $S$. Hammonia, there was a distinct increase in the LPS of medium length (L-OAg LPS).

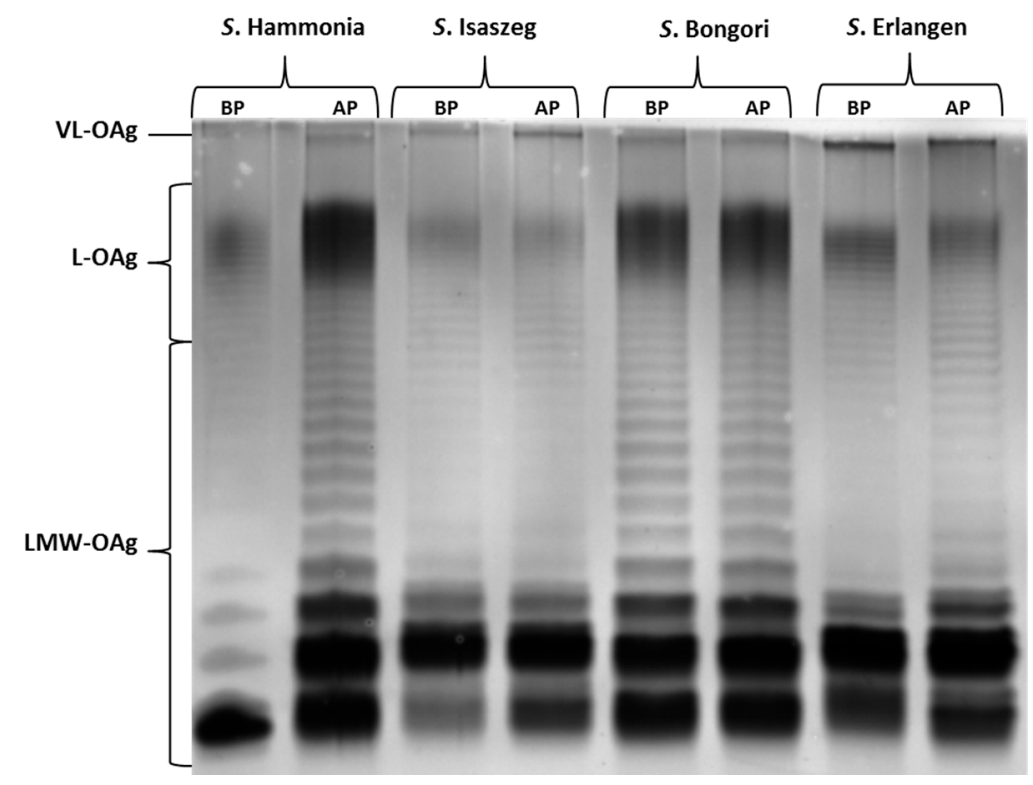

Figure 2. Lipopolysaccharide (LPS) profiles of four Salmonella $\mathrm{O} 48$ strains before (BP) and after (AP) nine passages in $50 \%$ normal human serum. VL-OAg: very long O-antigen; L-OAg: long O-antigen; LMW-OAg: low molecular weight O-antigen.

\subsection{GLC-MS/MS (Gas Liquid Chromatography-Mass Spectrometry) Analysis}

In the lipopolysaccharide molecule of O48 serotype, the number of Kdo (3-Deoxy-D-manno-octulosonic acid) residues is constant, while the number of repeating units in the O-antigen changes. Since each repeating unit of the O-antigen possesses one NeuAc (sialic acid) residue, the elongation of the O-antigen is directly linked to the increase in NeuAc content in the molecule. Therefore, we assume that NeuAc/Kdo proportions provide important information about the average length of the O-specific chain in the tested samples of bacteria. In our previous study, we analyzed the NeuAc/Kdo ratio in bacterial cells in minimal Falcov' medium using GLC-MS [19]. In the present study, we used a more sensitive GLC-MS/MS method; therefore, we could measure the NeuAc/Kdo ratio before and after passages in NHS in single bacterial colonies on agar plates (Figures 3 and 4). Each time, the amount of NeuAc was compared with the amount of Kdo in bacterial cells. The results showed that for all tested strains, the average length of the LPS O-antigen (measured as the NeuAc/Kdo ratio) increased after the passages of bacterial cells in $50 \%$ NHS, with relatively high variability of the LPS O-antigen length among colonies from the same strain (Figure 4). This indicates that results usually obtained for samples of bacterial cells mass are only an average of single cells values, which differ substantially. 


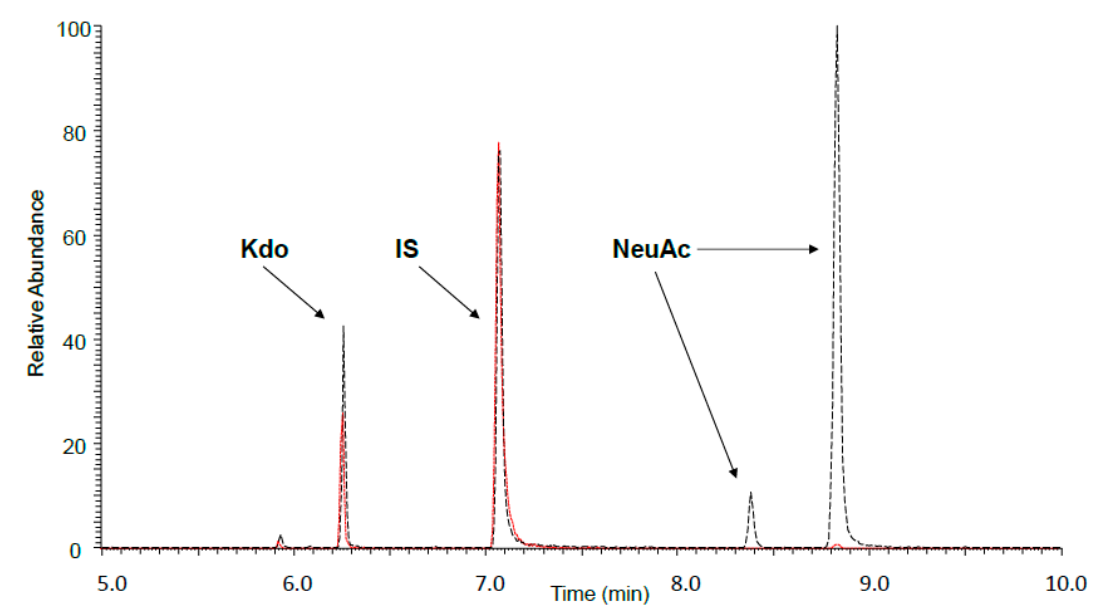

Figure 3. S. Erlangen results of analysis of two single colonies as an example showing high and low NeuAc (sialic acid)/Kdo (3-Deoxy-D-manno-octulosonic acid) ratio: colony 3 (black, dashed line) and colony 4 (red, dotted line) differing in NeuAc/Kdo ratio, superimposed for better view. MS/MS simultaneous analysis of Kdo (marker ion of $m / z=195$ ), NeuAc (ion of $m / z=386$ ), and perseitol (ion of $m / z=128$ ) as an internal standard (IS).

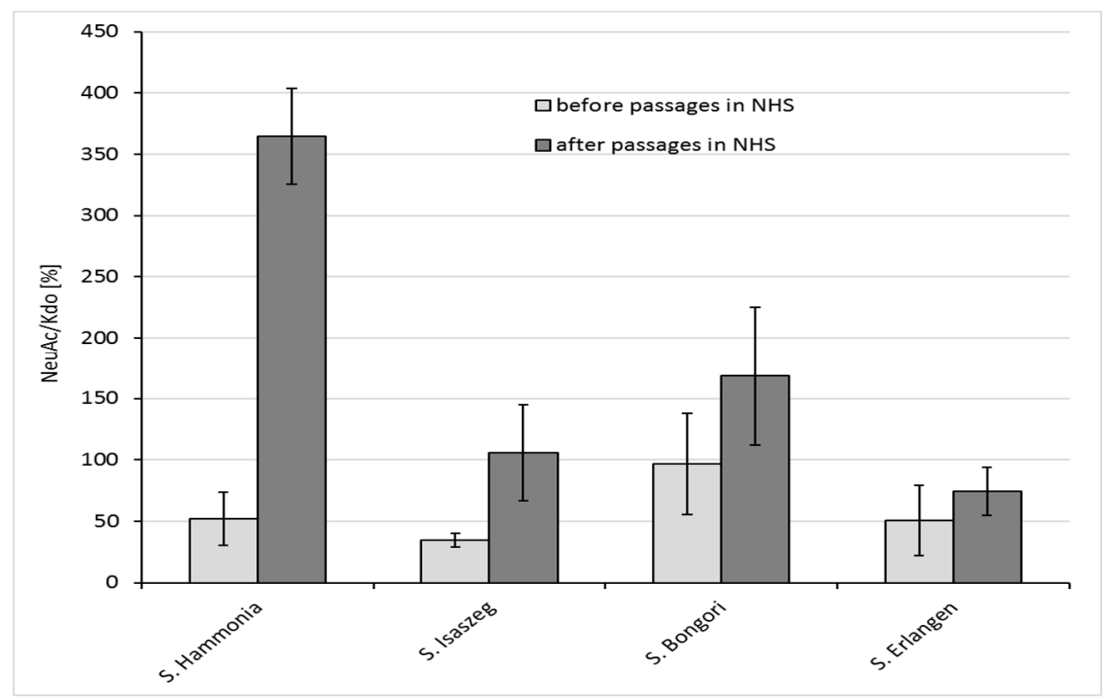

Figure 4. Results of GLC-MS/MS (Gas Liquid Chromatography-Mass Spectrometry) analysis of NeuAc/Kdo content (\%) in Salmonella O48 strains measured in single randomly selected colonies on agar plates (averaged results; $n=5$ ).

\section{Discussion}

Salmonella $\mathrm{O} 48$ are rare but very dangerous bacteria, especially for children under 5 years of age and immunocompromised patients. Gastroenteritis or sepsis caused by these strains is mainly related to contact with reptiles [13,24-27]. Complement plays a very important role in protecting the host from sepsis caused by pathogens, especially Gram-negative bacteria [2]. Passaging bacteria in NHS is a model of interaction between the host and pathogenic organism. Bacterial resistance to complement proteins is not yet fully explained. As some authors described a potential role of LPS in the serum resistance phenomenon [32,34,35], we tested whether changes in the LPS O-chain length can be a way of adaptation and resistance generation by Salmonella $\mathrm{O} 48$.

In our previous study [19], we did not find a clear correlation between the LPS O-antigen length (NeuAc/Kdo ratio) and the resistance of Salmonella O48 to bactericidal action of serum. 
Among the strains that were sensitive to serum action, we found both strains with long and short O-antigen. From that group of sensitive strains, we selected four strains of Salmonella O48 which varied substantially in the LPS O-antigen length for the experiments described in the present work. Here, we show that prolonged contact of bacteria with NHS results in the extension of the average LPS O-chain length, and that a very long O-antigen (VL-OAg) might protect bacteria from NHS action. The research results of Murray et al. [37,38] and Bravo et al. [35] showed that VL-OAg provides serum resistance of S. Typhimurium. Crawford et al. [39] proved the key role of VL-OAg in Salmonella Typhimurium resistance to bile. The O-antigen length is under the control of the $w z z$ gene. $w z z$ is under the control of OMPs (outer membrane proteins): OMP FepE controls VL-OAg production, and OMP Wzz controls L-OAg production [35]. However, it is still unclear as to what extent the genes and/or the environment are involved in this process. It is possible that both changes in the LPS length and the OMPs arrangement in OM (outer membrane) are responsible for bacterial adaptation and survival in the presence of serum proteins. Our experiments also include an analysis of Salmonella Enteritidis OMP changes in the serum resistance phenomenon. The results are described in our previous works [40-42]. Considering these results as well as those of our present findings, we suggest that it is possible that both long LPSs and certain OMPs (e.g., PgtE in S. Enteritidis) together provide resistance to the bactericidal action of serum. Apart from the serum, there are other environmental factors influencing the length of the LPS O-chain, e.g., growth temperature, lower amount of $\mathrm{Mg}^{2+}$ and $\mathrm{Fe}^{3+}$ in the environment, or the growth phase of bacterial cells [35]. In our study, single colonies of the same strain from one agar plate differed in the NeuAc/Kdo ratio. As Bravo et al. [35] showed that the longest O-chain is produced at the late exponential and stationary phase of growth, we suppose that this difference may be due to the growth phase or, alternatively, it can reflect the innate variability of the strains. Our results of the NeuAc/Kdo ratio in bacterial colonies show the average length of LPS, however, the variation of the O-antigen length between particular colonies of one strain is relatively high. One of the tested strains (S. Bongori) did not become resistant to serum after nine passages (survival rate of bacterial cells in $\mathrm{T} 3<100 \%$ ), although its susceptibility substantially changed. Before the passages, the strain was much more sensitive to serum than other tested Salmonella O48 serovars. During the passages, $S$. Bongori became more than four-fold more resistant to serum compared to before the passages. Also, the average length of the O-chain of this strain increased (Figure 4), suggesting a role of LPSs in bacterial adaptation to harsh environments.

\section{Materials and Methods}

\subsection{Bacterial Strains and Growth Conditions}

The study was carried out on four strains of Salmonella O48 serogroup: Salmonella bongori from serovar Bongori and Salmonella enterica from serovars: Erlangen, Isaszeg, and Hammonia. The strains were obtained from Polish Collection of Microorganisms (PCM), Hirszfeld Institute of Immunology and Experimental Therapy, Polish Academy of Sciences, Wroclaw, Poland. The list of the tested strains, showing their origin and antigenic characteristics, is presented in Table 3.

Table 3. The origin and antigenic characteristics of the Salmonella O48 strains used in this study.

\begin{tabular}{ccccc}
\hline Species & Subspecies & Serovar & Somatic (O) Antigen & Source \\
\hline Salmonella bongori & - & Bongori & 48 & $\mathrm{PCM}^{*} 2547$ \\
Salmonella enterica & enterica & Isaszeg & 48 & $\mathrm{PCM}^{*} 2550$ \\
Salmonella enterica & salamae & Erlangen & 48 & $\mathrm{PCM}^{*} 2533$ \\
Salmonella enterica & salamae & Hammonia & 48 & $\mathrm{PCM}^{*} 2535$ \\
\hline
\end{tabular}

* PCM-Polish Collection of Microorganisms, Hirszfeld Institute of Immunology and Experimental Therapy, Polish Academy of Sciences, Wroclaw, Poland. 


\subsection{Media}

For the bactericidal assay of human serum and LPS extraction, bacterial cells were grown in liquid medium (YP yeast extract-peptone broth: bactopeptone (Difco), yeast extract (Difco) and $\mathrm{NaCl}$ (POCh, Gliwice, Poland), pH 7.0) at $37^{\circ} \mathrm{C}$ for $18 \mathrm{~h}$ in a water bath with shaking. For GLC-MS/MS analysis, the bacteria were grown in minimal Falcov' medium $\left(\mathrm{K}_{2} \mathrm{HPO}_{4}, \mathrm{KH}_{2} \mathrm{PO}_{4}, \mathrm{MgSO}{ }_{4},\left(\mathrm{NH}_{4}\right)_{2} \mathrm{SO}_{4}\right.$, glucose and $\mathrm{NaCl}$, (all POCh, Gliwice, Poland)) and on nutrient agar plates (BIOCORP, Warszawa, Poland). For bacteria storage in $-70{ }^{\circ} \mathrm{C}$, LB medium with $50 \%$ glycerol (POCh, Gliwice, Poland) was used.

\subsection{Sera}

Normal human serum (NHS) was obtained from the Regional Center of Transfusion Medicine and Blood Bank, Wroclaw, Poland (120 donors) and was approved by the authors' institutional review board (Elżbieta Klausa, DG-G/2739/11, 18.05.2011). This was conducted according to the principles expressed in the Law on the public service of blood of 20 May 2016 and in the Directive 2002/98/EC of the European Parliament and of the Council of 27 January 2003, establishing standards of quality and safety for the collection, testing, processing, storage, and distribution of human blood and blood components. Blood samples were collected into sterile tubes with clot activator and gel for serum separation. The samples were then stored at room temperature (RT) for $30 \mathrm{~min}$. After that, the samples were centrifuged for $5 \mathrm{~min}$ at $3000 \mathrm{rpm}$. Only the serum samples without hemolysis and lipemia were used for experiments. The $\mathrm{C} 3$ concentration in the mixed serum was quantified by radial immunodiffusion (Human Complement C3 \& C4 "Nl" BindaridTM Radial Immunodiffusion Kit; The Binding site Group Ltd., Birmingham, UK). The collected serum was frozen in 0.5-mL aliquots at $-70{ }^{\circ} \mathrm{C}$ for no longer than six months. The required volume of serum was thawed immediately before each passage and each portion was used only once.

\subsection{Bactericidal Assay of NHS}

The bactericidal action of NHS against the tested strains was determined as described previously $[19,29]$ with slight modification. Bacterial cells were grown for $18 \mathrm{~h}$ in $5.0 \mathrm{~mL}$ of YP medium with shaking. Then $0.05 \mathrm{~mL}$ of the overnight bacterial culture was transferred to $3.0 \mathrm{~mL}$ of fresh YP medium and incubated at $37^{\circ} \mathrm{C}$ for $1 \mathrm{~h}$ in water bath with shaking. Next, bacterial cells were centrifuged ( $4000 \mathrm{rpm}$ for $20 \mathrm{~min}$ at $4{ }^{\circ} \mathrm{C}$ ) and the pellet was suspended in physiological saline $(0.9 \% \mathrm{NaCl})$. Then, $1.0 \mathrm{~mL}$ of the suspension was transferred into $5.0 \mathrm{~mL}$ of physiological saline and, after shaking, $0.5 \mathrm{~mL}$ of the resulting suspension was mixed with $0.5 \mathrm{~mL}$ of freshly thawed NHS. The purpose of such preparation was to obtain an early log-phase culture of bacteria mixed with serum and the initial colony forming units in $1.0 \mathrm{~mL}$ of medium was $10^{6} \mathrm{CFU} / \mathrm{mL}$ (colony-forming units in milliliter), which was verified each time. Bacterial cells mixed with serum were incubated in water bath with shaking at $37^{\circ} \mathrm{C}$ for $3 \mathrm{~h}$. The cells were collected after 0 (T0) and $3 \mathrm{~h}$ (T3). The collected samples were diluted and cultured on nutrient agar plates at $37^{\circ} \mathrm{C}$ for $18 \mathrm{~h}$. After $18 \mathrm{~h}$ of incubation, the average number of colonies was estimated from agar plates, then the CFU/mL was calculated and the value of $\mathrm{CFU} / \mathrm{mL}$ at $\mathrm{T} 0$ was taken as $100 \%$ of bacterial cells' survival. According to this value, the survival percent of bacterial cells in T3 was estimated. When the survival percent of bacterial cells in T3 was $>100 \%$, the cells were considered resistant, and those with survival rates $<100 \%$ were considered susceptible to $50 \%$ NHS bactericidal action. NHS decomplemented by heating at $56{ }^{\circ} \mathrm{C}$ for $30 \mathrm{~min}$ was used as a control (Table 2).

\subsection{Passages of Bacterial Cells in NHS}

Passages of bacterial cells in 50\% NHS were based on the method of bactericidal action of NHS described above. Every single passage was considered as an independent experiment on the bactericidal action of serum. Each tested strain was passaged in serum nine times. The number of 
passages was estimated in our previous study [43] as sufficient for changing bacterial susceptibility to NHS. The first passage was the first contact of the cells with complement. After conducting the first passage, 10 randomly chosen bacterial colonies obtained on agar plates from T3 were used to prepare the bacterial culture for passage 2. Those colonies were transferred into another $5 \mathrm{~mL}$ of fresh YP medium, and then the experiment was carried out as described for the method of bactericidal assay of NHS. The usage of fresh medium was necessary, as the NHS selective pressure was so high that after $3 \mathrm{~h}$ of incubation of Salmonella with NHS the survival ratio of the cells was too low to continue the experiment using NHS. That is why the cells from T3 were grown in medium without selective pressure, and they were again prepared to obtain $10^{6} \mathrm{CFU} / \mathrm{mL}$ and transferred back to NHS. Serial passages of bacterial cells in 50\% NHS were performed nine times, each time using colonies obtained on agar plates from T3 in the previous passage. The control was a parallel test using medium containing the same composition, however NHS was decomplemented by heating, as described above, to remove the selective pressure. Bacterial cells from passage 9 were transferred into fresh LB medium with glycerol and frozen in $-70{ }^{\circ} \mathrm{C}$ for further analysis.

\subsection{Isolation of Lipopolysaccharides and Analysis by SDS-PAGE (SDS-Polyacrylamide Gel Electrophoresis)}

Lipopolysaccharides were extracted from all of the tested Salmonella O48 strains before the passages and after ninth passage in 50\% NHS. The extraction was done using a commercial RNA isolating reagent according to Yi and Hackett [44]. Briefly, $10 \mathrm{mg}$ of lyophilized bacterial cells were suspended in $200 \mu \mathrm{L}$ of Tri-Reagent (Sigma-Aldrich, St. Louis, MO, USA). The cell suspension was then incubated at room temperature for $10 \mathrm{~min}$ for complete cell homogenization. After incubation, $200 \mu \mathrm{L}$ of chloroform was added to create a phase separation. The mixture was than vigorously vortexed and incubated at room temperature for an additional $10 \mathrm{~min}$. The resulting mixture was centrifuged at 14,000 rpm (Minispin Plus, Eppendorf, Hamburg, Germany) for 10 min to separate the aqueous and organic phase. The aqueous phase was transferred to a new 1.5-mL centrifuge tube. Distilled water $(100 \mu \mathrm{L})$ was added to the organic phase. The mixture was vortexed, incubated at room temperature for $10 \mathrm{~min}$, and centrifuged at 14,000 rpm for $10 \mathrm{~min}$. The upper aqueous phases from both steps were combined. The water extraction steps were repeated twice. The combined aqueous phase was lyophilized. After lyophilization, we used the cold magnesium precipitation procedure according to Darveau and Hancock for the purification of LPS [45]. LPS was dissolved in $500 \mu \mathrm{L}$ of $0.375 \mathrm{M}$ magnesium chloride (POCh) in $95 \%$ ethanol, stored at $-20{ }^{\circ} \mathrm{C}$, followed by centrifugation at $14,000 \mathrm{rpm}$ for $15 \mathrm{~min}$. The pellet was suspended in $200 \mu \mathrm{L}$ of distilled water and lyophilized.

LPS extracts were analyzed by discontinuous SDS-PAGE using a Laemmli buffer system [46]. Samples were applied to the slabs after mixing with Laemmli buffer (composed of $10 \mathrm{mM}$ Tris-HCL, glycerol, SDS, bromophenol blue) and heating at $98^{\circ} \mathrm{C}$ for $7 \mathrm{~min}$. Gel electrophoresis was performed using $6 \%$ polyacrylamide stacking gel and $15 \%$ separating gel. The SDS-PAGE separation of LPS was performed at a constant voltage (120 V), for 90 min using a Mini-Protean Tetra Cell apparatus (Bio-Rad, Hercules, CA, USA). The separated LPS was visualized using silver staining according to Tsai and Frasch [47] with Fomsgaard [48] and our own slight modifications [40]. The gels containing separated LPS were photographed using a GelDoc XR imaging system (Bio-Rad, Hercules, CA, USA) under white light.

\subsection{Preparation of Samples for GLC-MS/MS Analysis}

For the analysis of NeuAc content, a sample of bacteria was placed in a screw-capped tube and an internal standard (10 $\mu \mathrm{g}$ of perseitol (Koch-Light Laboratories Ltd., Suffolk, UK)) was added. The lyophilized sample was methanolized with $2 \mathrm{M} \mathrm{HCl}$ in $\mathrm{CH}_{3} \mathrm{OH}$ (Sigma-Aldrich, St. Louis, $\mathrm{MO}$, USA) for $1 \mathrm{~h}$ at $80^{\circ} \mathrm{C}$, evaporated with a stream of $\mathrm{N}_{2}$ at $40^{\circ} \mathrm{C}$, and acetylated with $100 \mu \mathrm{L}$ of acetic anhydride (Sigma-Aldrich) and $20 \mu \mathrm{L}$ of pyridine (Sigma-Aldrich, St. Louis, MO, USA) at $80^{\circ} \mathrm{C}$ for $30 \mathrm{~min}$. After acetylation, the sample was dried with $\mathrm{N}_{2}$, dissolved in $100 \mu \mathrm{L}$ of ethyl acetate (POCh, Gliwice, Poland), and $1 \mu \mathrm{L}$ was taken for GLC-MS/MS analysis. 


\subsection{GLC-MS/MS Analysis}

Samples were analyzed by the GLC-MS/MS system: Thermo FOCUS GC with ITQ 700 ion trap detector with external ionization, equipped with Rxi- $5 \mathrm{~ms}$ column: $30 \mathrm{~m}, 0.25 \mathrm{~mm}$ ID (Restek, Bellefonte, PA, USA). In the GC method, the ion source temperature was set at $250{ }^{\circ} \mathrm{C}$ with automatic ionization energy. Then, $1 \mu \mathrm{L}$ of the sample was injected with split injection (split =10). The MS/MS analysis of peracetylated methyl ester of NeuAc methyl glycoside was performed with an ion of $m / z 446$ as a primary ion, which was isolated and fragmented. The secondary fragment of $m / z 386$ was used for the quantitation of NeuAc derivative in the sample. Kdo analysis was performed as described previously [49]. Soon after that, a primary ion of $m / z 375$ was isolated from the mass spectrum of peracetylated methyl ester ethyl glycoside of Kdo and fragmented; a secondary ion of $m / z 195$ was used for the quantitation of Kdo.

\subsection{Standard Curve for NeuAc Determination by GLC-MS/MS Method}

NeuAc standard $(1,3,10,30,100$, and $300 \mu \mathrm{g} / \mathrm{mL}$ ) with perseitol as an internal standard (1000 ng) were methanolized $\left(2 \mathrm{M} \mathrm{HCl} / \mathrm{CH}_{3} \mathrm{OH}, 80^{\circ} \mathrm{C}, 1 \mathrm{~h}\right)$, dried with a stream of $\mathrm{N}_{2}$, and acetylated with $200 \mu \mathrm{L}$ acetic anhydride and $20 \mu \mathrm{L}$ pyridine at $80^{\circ} \mathrm{C}$ for $30 \mathrm{~min}$. Samples were dissolved in $100 \mu \mathrm{L}$ of ethyl acetate for GLC-MSMS analysis.

In our previous study [19], we performed GLC-MS/MS analysis of the NeuAc/Kdo ratio in bacterial Salmonella O48 cells in minimal Falcov' medium. In this study, we decided to increase the spectrum of research. We measured the NeuAc/Kdo ratio before and after passages in NHS in bacterial cells grown in minimal Falcov' medium, and single bacterial colonies taken from agar plates.

\section{Conclusions}

Our study shows that prolonged contact of Salmonella cells with serum results in the adaptation of the bacteria to adverse environmental conditions. The resistance of Salmonella $\mathrm{O} 48$ to the bactericidal action of the serum has a multifactorial basis. However, our results show that LPS O-chain elongation plays a significant role in this phenomenon. Present findings constitute a significant basis for the huge field of exploration, that will involve more detailed studies on the possible changes in the length and structure of LPS upon challenging bacteria with complement proteins (especially the acetylation pattern of the resulting lipopolysaccharide molecule).

In our opinion, the results clearly show that multiple passages of bacteria in human serum lead to the resistance of the cells to the serum. There is a very significant change in the LPS O-chain length between cells before and after multiple passages in serum. That is why we deduced that the elongation of LPS protects bacteria from the bactericidal action of serum. We did not show the exact mechanism of how this elongation protects bacteria from serum action; however, we can presume that either the increased amount of sialic acid causes the molecular mimicry phenomenon or the VL-OAg creates a barrier around the cell, so the complement proteins cannot reach the cell surface. An explanation of this process is our team's goal for the next investigation.

Acknowledgments: The authors thank: Prof. Dr hab. A. Gamian (Polish Academy of Sciences, Wroclaw, Poland) for the Salmonella O48 strains from the Polish Collection of Microorganisms, and Dr Kamila Myka (Department of Microbiology and Immunology, Columbia University, New York, NY, USA) for English changes. This research was supported in part by a grant funded by University of Wroclaw-project nr 2015/M/IGM/12. Publication was also supported by Wroclaw Centre of Biotechnology, programme The Leading National Research Centre (KNOW) for years 2014-2018. The funding agency (KNOW) had no direct role in the conduct of the study, the collection, management, and interpretation of the data, preparation, nor approval of the manuscript.

Author Contributions: Jacek Rybka, Gabriela Bugla-Płoskońska, Aleksandra Pawlak conceived and designed the experiments; Jacek Rybka, Gabriela Bugla-Płoskońska, Aleksandra Pawlak obtained funding, Aleksandra Pawlak, Bartłomiej Dudek, Eva Krzyżewska, Wojciech Rybka performed the experiments; Aleksandra Pawlak, Bartłomiej Dudek, Eva Krzyżewska, Jacek Rybka, Gabriela Bugla-Płoskońska analyzed the data; Aleksandra Pawlak, Gabriela Bugla-Płoskońska, Jacek Rybka, Eva Krzyżewska, Elżbieta Klausa contributed reagents/materials/analysis tools; Aleksandra Pawlak, Bartłomiej Dudek, Eva Krzyżewska, Anna Kędziora, 
Jacek Rybka, Gabriela Bugla-Płoskońska wrote the paper. Gabriela Bugla-Płoskońska and Jacek Rybka provided study supervision. All co-authors revised and approved the final manuscript.

Conflicts of Interest: The authors declare no conflicts of interest.

\section{Abbreviations}

$\begin{array}{ll}\text { LPS } & \text { lipopolysaccharide } \\ \text { VL-OAg } & \text { very long O-antigen } \\ \text { Kdo } & \text { 3-Deoxy-D-manno-octulosonic acid } \\ \text { L-OAg } & \text { long O-antigen } \\ \text { CDC } & \text { Center for Disease Control and Prevention } \\ \text { NeuAc } & \text { sialic acid } \\ \text { NTS } & \text { non-typhoidal salmonellosis } \\ \text { RAS } & \text { reptile-associated salmonellosis } \\ \text { REPAS } & \text { reptile exotic pet associated salmonellosis } \\ \text { NHS } & \text { normal human serum } \\ \text { CFU } & \text { colony forming units } \\ \text { OMP } & \text { outer membrane protein } \\ \text { GLC-MS } & \text { gas liquid chromatography-mass spectrometry } \\ \text { PCM } & \text { Polish Collection of Microorganisms } \\ \text { SDS-PAGE } & \text { SDS-polyacrylamide gel electrophoresis }\end{array}$

\section{References}

1. Markiewski, M.M.; DeAngelis, R.A.; Lambris, J.D. Complexity of complement activation in sepsis. J. Cell. Mol. Med. 2008, 12, 2245-2254. [CrossRef] [PubMed]

2. Haeney, M.R. The role of the complement cascade in sepsis. J. Antimicrob. Chemother. 1998, 41 (Suppl. A), 41-46. [CrossRef] [PubMed]

3. Heikema, A.P.; Koning, R.I.; Duarte dos Santos Rico, S.; Rempel, H.; Jacobs, B.C.; Endtz, H.P.; van Wamel, W.J.B.; Samsom, J.N. Enhanced, Sialoadhesin-dependent uptake of Guillain-Barre syndrome-associated Campylobacter jejuni strains by human macrophages. Infect. Immun. 2013, 81, $2095-2103$. [CrossRef] [PubMed]

4. Spinola, S.M.; Li, W.; Fortney, K.R.; Janowicz, D.M.; Zwickl, B.; Katz, B.P.; Munson, R.S. Sialylation of lipooligosaccharides is dispensable for the virulence of Haemophilus ducreyi in humans. Infect. Immun. 2012, 80, 679-687. [CrossRef] [PubMed]

5. Bax, M.; Kuijf, M.L.; Heikema, A.P.; van Rijs, W.; Bruijns, S.C.; García-Vallejo, J.J.; Crocker, P.R.; Jacobs, B.C.; van Vliet, S.J.; van Kooyk, Y. Campylobacter jejuni lipooligosaccharides modulate dendritic cell-mediated T cell polarization in a sialic acid linkage-dependent manner. Infect. Immun. 2011, 79, 2681-2689. [CrossRef] [PubMed]

6. Majowicz, S.E.; Musto, J.; Scallan, E.; Angulo, F.J.; Kirk, M.; O’Brien, S.J.; Jones, T.F.; Fazil, A.; Hoekstra, R.M. International Collaboration on Enteric Disease "Burden of Illness" studies The global burden of nontyphoidal Salmonella gastroenteritis. Clin. Infect. Dis Off. Publ. Infect. Dis. Soc. Am. 2010, 50, 882-889. [CrossRef] [PubMed]

7. Rondini, S.; Micoli, F.; Lanzilao, L.; Gavini, M.; Alfini, R.; Brandt, C.; Clare, S.; Mastroeni, P.; Saul, A.; MacLennan, C.A. Design of glycoconjugate vaccines against invasive African Salmonella enterica serovar Typhimurium. Infect. Immun. 2015, 83, 996-1007. [CrossRef] [PubMed]

8. LaRock, D.L.; Chaudhary, A.; Miller, S.I. Salmonellae interactions with host processes. Nat. Rev. Microbiol. 2015, 13, 191-205. [CrossRef] [PubMed]

9. Onsare, R.S.; Micoli, F.; Lanzilao, L.; Alfini, R.; Okoro, C.K.; Muigai, A.W.; Revathi, G.; Saul, A.; Kariuki, S.; MacLennan, C.A.; et al. Relationship between antibody susceptibility and lipopolysaccharide O-antigen characteristics of invasive and gastrointestinal nontyphoidal Salmonellae isolates from Kenya. PLos Negl. Trop. Dis. 2015, 9, e0003573. [CrossRef] [PubMed]

10. Marshall, J.M.; Gunn, J.S. The O-Antigen Capsule of Salmonella enterica serovar Typhimurium Facilitates serum Resistance and surface Expression of FliC. Infect. Immun. 2015, 83, 3946-3959. [CrossRef] [PubMed] 
11. Tennant, S.M.; Wang, J.Y.; Galen, J.E.; Simon, R.; Pasetti, M.F.; Gat, O.; Levine, M.M. Engineering and preclinical evaluation of attenuated nontyphoidal Salmonella strains serving as live oral vaccines and as reagent strains. Infect. Immun. 2011, 79, 4175-4185. [CrossRef] [PubMed]

12. Keestra-Gounder, A.M.; Tsolis, R.M.; Bäumler, A.J. Now you see me, now you don't: The interaction of Salmonella with innate immune receptors. Nat. Rev. Microbiol. 2015, 13, 206-216. [CrossRef] [PubMed]

13. Hoelzer, K.; Moreno Switt, A.I.; Wiedmann, M. Animal contact as a source of human non-typhoidal salmonellosis. Vet. Res. 2011, 42, 34. [CrossRef] [PubMed]

14. Liu, B.; Knirel, Y.A.; Feng, L.; Perepelov, A.V.; Senchenkova, S.N.; Reeves, P.R.; Wang, L. Structural diversity in Salmonella $\mathrm{O}$ antigens and its genetic basis. FEMS Microbiol. Rev. 2014, 38, 56-89. [CrossRef] [PubMed]

15. Parry, C.M.; Thomas, S.; Aspinall, E.J.; Cooke, R.P.D.; Rogerson, S.J.; Harries, A.D.; Beeching, N.J. A retrospective study of secondary bacteraemia in hospitalised adults with community acquired non-typhoidal Salmonella gastroenteritis. BMC Infect. Dis. 2013, 13, 107. [CrossRef] [PubMed]

16. Van Meervenne, E.; Botteldoorn, N.; Lokietek, S.; Vatlet, M.; Cupa, A.; Naranjo, M.; Dierick, K.; Bertrand, S. Turtle-associated Salmonella septicaemia and meningitis in a 2-month-old baby. J. Med. Microbiol. 2009, 58, 1379-1381. [CrossRef] [PubMed]

17. Schneider, L.; Ehlinger, M.; Stanchina, C.; Giacomelli, M.-C.; Gicquel, P.; Karger, C.; Clavert, J.-M. Salmonella enterica subsp. arizonae bone and joints sepsis. A case report and literature review. Orthop. Traumatol. Surg. Res. 2009, 95, 237-242. [CrossRef] [PubMed]

18. Gyang, A.; Saunders, M. Salmonella Mississippi: A rare cause of second trimester miscarriage. Arch. Gynecol. Obstet. 2008, 277, 437-438. [CrossRef] [PubMed]

19. Bugla-Płoskońska, G.; Rybka, J.; Futoma-Kołoch, B.; Cisowska, A.; Gamian, A.; Doroszkiewicz, W. Sialic acid-containing lipopolysaccharides of Salmonella $\mathrm{O} 48$ strains-potential role in camouflage and susceptibility to the bactericidal effect of normal human serum. Microb. Ecol. 2010, 59, 601-613. [CrossRef] [PubMed]

20. Pees, M.; Rabsch, W.; Plenz, B.; Fruth, A.; Prager, R.; Simon, S.; Schmidt, V.; Munch, S.; Braun, P. Evidence for the transmission of Salmonella from reptiles to children in Germany, July 2010 to October 2011. Euro Surveill. 2013, 18. Available online: http:/ / www.eurosurveillance.org/ViewArticle.aspx?ArticleId= 20634 (accessed on 1 August 2017). [CrossRef]

21. Friedman, C.R.; Torigian, C.; Shillam, P.J.; Hoffman, R.E.; Heltzel, D.; Beebe, J.L.; Malcolm, G.; DeWitt, W.E.; Hutwagner, L.; Griffin, P.M. An outbreak of salmonellosis among children attending a reptile exhibit at a zoo. J. Pediatr. 1998, 132, 802-807. [CrossRef]

22. Geue, L.; Löschner, U. Salmonella enterica in reptiles of German and Austrian origin. Vet. Microbiol. 2002, 84, 79-91. [CrossRef]

23. Mermin, J.; Hoar, B.; Angulo, F.J. Iguanas and Salmonella marina infection in children: A reflection of the increasing incidence of reptile-associated salmonellosis in the United States Pediatrics. Pediatrics 1997, 99, 399-402. [CrossRef] [PubMed]

24. Cain, C.; Tyre, D.; Ferraro, D. Incidence of Salmonella on Reptiles in the Pet Trade. Rev. Undergrad. Res Agric. Life Sci. 2009, 4, 1.

25. O'Byrne, A.M.; Mahon, M. Reptile-associated salmonellosis in residents in the south East of Ireland 2005-2007. Eurosurveillance 2008, 13, 1854-1861.

26. Schröter, M.; Roggentin, P.; Hofmann, J.; Speicher, A.; Laufs, R.; Mack, D. Pet snakes as a reservoir for Salmonella enterica subsp. diarizonae (serogroup IIIb): A prospective study. Appl. Environ. Microbiol. 2004, 70, 613-615.

27. Warwick, C.; Lambiris, A.J.; Westwood, D.; Steedman, C. Reptile-related salmonellosis. J. R. Soc. Med. 2001, 94, 124-126. [CrossRef] [PubMed]

28. Gamian, A.; Jones, C.; Lipiński, T.; Korzeniowska-Kowal, A.; Ravenscroft, N. Structure of the sialic acid-containing O-specific polysaccharide from Salmonella enterica serovar Toucra O48 lipopolysaccharide. Eur. J. Biochem. FEBs 2000, 267, 3160-3167. [CrossRef]

29. Ram, S.; Sharma, A.K.; Simpson, S.D.; Gulati, S.; McQuillen, D.P.; Pangburn, M.K.; Rice, P.A. A Novel sialic Acid Binding site on Factor H Mediates serum Resistance of sialylated Neisseria gonorrhoeae. J. Exp. Med. 1998, 187, 743-752. [CrossRef] [PubMed]

30. Ilg, K.; Zandomeneghi, G.; Rugarabamu, G.; Meier, B.H.; Aebi, M. HR-MAs NMR reveals a pH-dependent LPS alteration by de-O-acetylation at abequose in the O-antigen of Salmonella enterica serovar Typhimurium. Carbohydr. Res. 2013, 382, 58-64. [CrossRef] [PubMed] 
31. Basu, S.; Schlecht, S.; Wagner, M.; Mayer, H.L. The sialic acid-containing lipopolysaccharides of Salmonella djakarta and Salmonella isaszeg (serogroup O: 48): Chemical characterization and reactivity with a sialic acid-binding lectin from Cepaea hortensis. FEMS Immunol. Med. Microbiol. 1994, 9, 189-197. [CrossRef] [PubMed]

32. Matsuura, M. Structural Modifications of Bacterial Lipopolysaccharide that Facilitate Gram-Negative Bacteria Evasion of Host Innate Immunity. Front. Immunol. 2013, 4, 109. [CrossRef] [PubMed]

33. Munn, C.B.; Ishiguro, E.E.; Kay, W.W.; Trust, T.J. Role of surface components in serum resistance of virulent Aeromonas salmonicida. Infect. Immun. 1982, 36, 1069-1075. [PubMed]

34. Taylor, P.W. Bactericidal and bacteriolytic activity of serum against gram-negative bacteria. Microbiol. Rev. 1983, 47, 46-83. [PubMed]

35. Bravo, D.; Silva, C.; Carter, J.A.; Hoare, A.; Alvarez, S.A.; Blondel, C.J.; Zaldívar, M.; Valvano, M.A.; Contreras, I. Growth-phase regulation of lipopolysaccharide O-antigen chain length influences serum resistance in serovars of Salmonella. J. Med. Microbiol. 2008, 57, 938-946. [CrossRef] [PubMed]

36. Vimr, E.R. Unified theory of bacterial sialometabolism: How and why bacteria metabolize host sialic acids. ISRN Microbiol. 2013, 2013, 816713. [CrossRef] [PubMed]

37. Murray, G.L.; Attridge, S.R.; Morona, R. Regulation of Salmonella typhimurium lipopolysaccharide O antigen chain length is required for virulence; identification of FepE as a second Wzz. Mol. Microbiol. 2003, 47, 1395-1406. [CrossRef] [PubMed]

38. Murray, G.L.; Attridge, S.R.; Morona, R. Inducible serum resistance in Salmonella typhimurium is dependent on wzz (fepE)-regulated very long O antigen chains. Microbes Infect. 2005, 7, 1296-1304. [CrossRef] [PubMed]

39. Crawford, R.W.; Keestra, A.M.; Winter, S.E.; Xavier, M.N.; Tsolis, R.M.; Tolstikov, V.; Bäumler, A.J. Very long O-antigen chains enhance fitness during Salmonella-induced colitis by increasing bile resistance. PLoS Pathog. 2012, 8, e1002918. [CrossRef] [PubMed]

40. Dudek, B.; Krzyżewska, E.; Kapczyńska, K.; Rybka, J.; Pawlak, A.; Korzekwa, K.; Klausa, E.; Bugla-Płoskońska, G. Proteomic Analysis of Outer Membrane Proteins from Salmonella Enteritidis strains with Different sensitivity to Human serum. PLoS ONE 2016, 11, e0164069. [CrossRef] [PubMed]

41. Bugla-Płoskońska, G.; Korzeniowska-Kowal, A.; Guz-Regner, K. Reptiles as a source of Salmonella O48-Clinically important bacteria for children: The relationship between resistance to normal cord serum and outer membrane protein patterns. Microb. Ecol. 2011, 61, 41-51. [CrossRef] [PubMed]

42. Futoma-Koloch, B.; Bugla-Ploskonska, G.; Sarowska, J. Searching for Outer Membrane Proteins Typical of serum-sensitive and serum-Resistant Phenotypes of Salmonella. In Salmonella-Distribution, Adaptation, Control Measures and Molecular Technologies; InTech: Rijeka, Croatia, 2012; pp. 265-290.

43. Skwara, A.; Dudek, B.; Rybka, J.; Rybka, W.; Klausa, E.; Doroszkiewicz, W.; Gamian, A.; Bugla-Płoskońska, G. Zmiany w ilości kwasu sjalowego w lipopolisacharydach pałeczek Salmonella O48 po pasażach w surowicy ludzkiej (in polish). In Proceedings of the Zjazd PTM, Lublin, Poland, 5-8 September 2012.

44. Yi, E.C.; Hackett, M. Rapid isolation method for lipopolysaccharide and lipid A from gram-negative bacteria. Analyst 2000, 125, 651-656. [CrossRef] [PubMed]

45. Darveau, R.P.; Hancock, R.E. Procedure for isolation of bacterial lipopolysaccharides from both smooth and rough Pseudomonas aeruginosa and Salmonella typhimurium strains. J. Bacteriol. 1983, 155, 831-838. [PubMed]

46. Laemmli, U.K. Cleavage of structural proteins during the assembly of the head of bacteriophage T4. Nature 1970, 227, 680-685. [CrossRef] [PubMed]

47. Tsai, C.M.; Frasch, C.E. A sensitive silver stain for detecting lipopolysaccharides in polyacrylamide gels. Anal. Biochem. 1982, 119, 115-119.

48. Fomsgaard, A.; Freudenberg, M.A.; Galanos, C. Modification of the silver staining technique to detect lipopolysaccharide in polyacrylamide gels. J. Clin. Microbiol. 1990, 28, 2627-2631. [PubMed]

49. Rybka, J.; Gamian, A. Determination of endotoxin by the measurement of the acetylated methyl glycoside derivative of Kdo with gas-liquid chromatography-mass spectrometry. J. Microbiol. Methods 2006, 64, 171-184. [CrossRef] [PubMed]

(C) 2017 by the authors. Licensee MDPI, Basel, Switzerland. This article is an open access article distributed under the terms and conditions of the Creative Commons Attribution (CC BY) license (http://creativecommons.org/licenses/by/4.0/). 